\title{
The Web-based Learning Environment in General Physics Course in a Public University in Kyrgyzstan
}

\author{
Gulshat Muhametjanova ${ }^{1^{*}}$, Azat Akmatbekova ${ }^{1}$ \\ ${ }^{1}$ Kyrgyz Turkish Manas University, Kyrgyz Turkish Manas University/Bishkek/Kyrgyzstan, 720000 Bishkek, KYRGYZSTAN
}

Received 8 October 2018 • Revised 23 November 2018 • Accepted 29 November 2018

\begin{abstract}
This study was conducted to see the attitudes of students toward web-based learning environment in General Physics course. The study was conducted in a public university in Kyrgyzstan in 2018. 144 students from the faculty of Science and Engineering participated in the study. Online questionnaire was completed online at the end of the spring semester 2017-2018. In addition, in-depth interviews with 12 students were conducted. Results showed that students' success in online Physics course depends on gender and academic major of students. Factors, that were defined in this study: advantages over traditional methods, and fear of using online course were also found to be significant for students' success in completing online Physics course while ease of use was found to be non-significant. In interviews with students, 2 major points were highlighted, namely, lack of online education experience among students and internet connection problems.
\end{abstract}

Keywords: web-based learning, modern Physics, online learning, Kyrgyzstan

\section{INTRODUCTION}

Online learning and web-based learning environments are widely used throughout the world. It is really difficult to imagine modern learning and teaching a course without using technology. Learning Physics is not an exception. Despite the fact that learning Physics is a comprehensive task even face to face currently there a lot of tools which makes learning Physics easier and fun with use of technology. This study was conducted at a public university in Kyrgyzstan. The web-based learning environment was created with all necessary materials and resources, which students could use 24 hours per day. Web-based learning environment included all lectures in the Kyrgyz language online, online videos related with each topic, animations, and virtual laboratory. The current web-based learning environment for learning Physics is unique because there is no similar environment in the whole Kyrgyzstan with all information presented in the Kyrgyz language. Kyrgyzstan is a post-Soviet country and most of the learning materials can be accessed mostly in the Russian language. There are 2 official languages in Kyrgyzstan: Russian and Kyrgyz. However, there were lacks of materials not only online but in the Kyrgyz Language.

\section{LITERATURE REVIEW}

Learning Physics is an extremely comprehensive task. If material presented to young people in an uninteresting manner in the form of formulas students will be not motivated to learn it at all (Акматбекова, 2017). However, Information and Communication Technologies (ICT) gives us an opportunity to present information using modern technology in an interesting, and interactive form. Moreover, using online learning resources during performing laboratory work helps to increase motivation of students in learning complex topics, increase effectiveness of students' independent work, to understand the topic more in-depth and be able to use it in practice, stimulate students to be more proficient in using personal computers, and to measure the progress of students during semester (Акматбекова, 2017). Furthermore, as it was reported by Bingimlas, K. А. (2009) in a review made by Kelleher (2000) teaching science ICT cannot replace classroom teaching but ICT could be a positive force in the

(C) 2019 by the authors; licensee Modestum Ltd., UK. This article is an open access article distributed under the terms and conditions of the Creative Commons Attribution License (http://creativecommons.org/licenses/by/4.0/). \gulshatka@gmail.com (*Correspondence) \ayarka2009@list.ru 


\section{Contribution of this paper to the literature}

- While the great popularity and high use of web-based learning environments in education, there is only a few focusing on the attitudes of students in learning Physics course online in Kyrgyzstan.

- Web-based learning environment uniqueness is that all information is presented in Kyrgyz language.

- Factors defined in the study, together with demographic information like gender and academic major are found to be significant in being successful in Physics course.

- Online quizzes, which were used to measure their progress in learning each part, and get an immediate feedback on each quiz question.

- This study contributes to the existing literature by showing that the perceptions of the students towards online learning differ in the cross-cultural context.

science classroom to understand the concepts and principles on some topic deeper, and could be used to provide motivating, interesting, and successful educational activities.

Together with this, in a study conducted in the post-Soviet country on the use of ICT in learning STEM (Science, Technology, Engineering, and Mathematics) education showed that students have a positive attitude toward express tests prepared in PowerPoint due to the high interactivity, and object animation. However, as barrier students complained about the order of tests, so that they cannot switch to the necessary question and return back (Altshuler et al., 2015).

A study was conducted by Brown, I. T. (2002) on factors affecting perceived ease of use of web-based learning technologies in developing countries. Ease of finding and ease of understanding, self-efficacy, and computer anxiety influence perceived ease of use of web-based learning technologies. Perceived usefulness were not a significant influence on usage, while perceived ease of use influenced both usage and perceived usefulness. In another cross-cultural study conducted by Grandon et al. (2005) it was found that for the United States students' convenience, quality, subjective norms, and perceived ease of use were significant predictors of students' intention to use the online course. However, for Korean students only quality and subjective norms were found to be significant factors influencing their intentions to use online courses. Furthermore, in a study conducted by Voler and Lord (2000) in Australian university on critical success factors in online education it was found that factors as technology, the instructor and the previous use of the technology from a student's point of view were identified to be critical.

Furthermore, in a mixed-method study conducted in a public university in Kyrgyzstan on students' use of ICT during education it was found that computer cost and internet connection were one of the major barriers for students, while instructors have a limited knowledge and experience with technology, lack of technical support, lack of software and hardware, lack of time for ICT integration in classroom and lack of materials for instruction (Muhametjanova \& Cagiltay, 2016). As the study shows university instructors have to translate resources from Russian to the Kyrgyz language, and that's why both students and instructors face the difficulties due to the shortage of resources. It can be seen that there was a lack of materials and resources reported not online, but paperbased.

\section{METHODOLOGY}

\section{Participants}

A sample for this study consisted of students of faculty of Science and Engineering, who were enrolled in General Physics course. Students were from three departments of Science (Applied Mathematics and Informatics, Mathematics, and Biology), and four departments of Engineering (Chemical Engineering, Food Engineering, Ecology, and Computer Engineering) completed the online survey in spring 2017-2018 academic year. The total number of respondents was 144 students of age between 18 and 21 , with $36.1 \%$ males and $63.9 \%$ of female students participated in this study. The majority of students take the General Physics course for the first time (67.4\%).

\section{Materials and Procedure}

The current web-based learning environment was developed using interactive models, animations, constructors, video materials related to each lecture, virtual laboratories, and online quizzes for knowledge and progress evaluations. Students used a web-based learning environment with necessary quizzed throughout of the Spring Semester 2017-2018. After each lecture they had to take a quiz contacting 10 questions. Time for completing the online quiz was 20 minutes and after completing a quiz student can get immediate feedback to see what mistakes were made, and how it should be. After all lectures and quizzes were completed students were asked to complete the online questionnaire using Google forms. 
Table 1. Reliability test

\begin{tabular}{ccc}
\hline & \multicolumn{2}{c}{ Reliability Statistics } \\
\hline Cronbach's Alpha & Cronbach's Alpha Based on Standardized Items & N of Items \\
\hline .785 & .802 & 22 \\
\hline
\end{tabular}

Table 2. Kaiser-Meyer-Olkin and Bartlett's Test

\begin{tabular}{|c|c|c|}
\hline \multicolumn{2}{|c|}{ Kaiser-Meyer-Olkin Measure of Sampling Adequacy. } & .901 \\
\hline \multirow{3}{*}{ Bartlett's Test of Sphericity } & Approx. Chi-Square & 653.271 \\
\hline & $\mathrm{df}$ & 66 \\
\hline & Sig. & .000 \\
\hline
\end{tabular}

Table 3. Factor loadings

\begin{tabular}{|c|c|c|c|}
\hline \multicolumn{4}{|l|}{ Rotated Component Matrix ${ }^{a}$} \\
\hline & \multicolumn{3}{|c|}{ Component } \\
\hline & 1 & 2 & 3 \\
\hline Online testing is a modern approach to check the knowledge than traditional & .811 & & \\
\hline I want to continue submitting independent work online in other courses too & .746 & & \\
\hline Online testing has high objectivity and consequently more positive stimulating influence on our knowledge gaining & .743 & & \\
\hline Online testing saves my time during performing independent laboratory work & .529 & .626 & \\
\hline Independent work give me more responsibility in time management & & .847 & \\
\hline Getting immediate results and feedback from system online motivates me & & .563 & \\
\hline I wish to continue submitting independent work online for General Physics course & .414 & .572 & \\
\hline It is more comfortable for me to submit independent work online than in a written form & .722 & & \\
\hline Testing environment online is simple and easy to use & .435 & .489 & \\
\hline I like performing independent work online & .588 & .505 & \\
\hline Online tests helped me to pass a physics test & .552 & .367 & \\
\hline I had experienced some difficulties with computer or internet access during performing independent work online & & & .587 \\
\hline Online evaluation methods scare me & & & .682 \\
\hline I don't like online testing & & & .692 \\
\hline Video lectures helped me to perform independent work & & .518 & \\
\hline
\end{tabular}

Extraction Method: Principal Component Analysis.

Rotation Method: Varimax with Kaiser Normalization.

a. Rotation converged in 5 iterations.

\section{Questionnaire}

The online survey was conducted to analyze the usability of a web-based learning environment, and to see the attitudes of students toward online tests. The survey was adapted on the basis of a survey developed and used by (Demirci, 2007). It is consists of 38 questions with 6 items regarding Demographic information of participants, questions about general computer proficiency level, and 22 items with 5 point Likert-type questions (1-totally disagree, 2- disagree, 3- no idea, 4-agree, and 5- totally agree) related to students perceptions about web-based learning environments, and open-ended questions. To assess instrument internal consistency, Cronbach's alpha was calculated as .785 (Table 1), which is accepted as high internal consistency (McCrae et al., 2011).

\section{Interviews}

In addition to the online survey, semi-structured in-depth interviews with students were carried after completing of online surveys. Interviews were carried out with 12 students using purposeful sampling to provide more in-depth data, and to help to explain the results of the survey. Particularly, questions regarding their attitudes toward web-based learning environments, its advantages and shortcomings, students' expectations were asked.

\section{Factor Analysis}

Kaiser-Meyer-Olkin and Bartlett's Test was conducted to measure the sampling adequacy. The result is shown in Table 2. Kaiser-Meyer-Olkin Measure of Sampling Adequacy is equal to 0.901, which is close to 1. In addition, the null hypothesis for Bartlett's Test of Sphericity is rejected, since p-value is 0.000 . That's why; the data reduction is possible for this dataset. Next, Principal Component factor analysis was conducted. The result of the rotated component matrix suggested three different factors. Factor loadings for all variables were greater than 0.414 and are given in the (Table 3 ). 


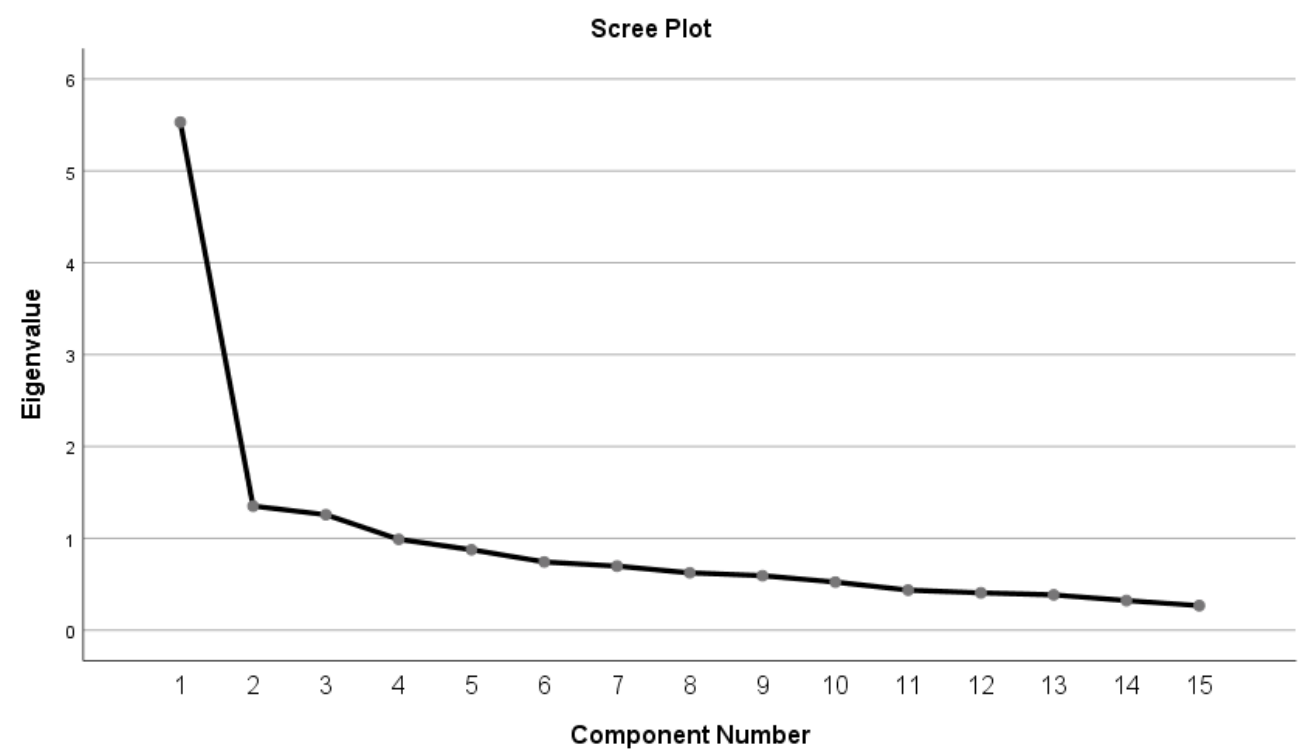

Figure 1. Scree Plot

3 factors can be described as:

1. Ease of use

2. Advantages over traditional methods

3. Fear of using

Cumulative percentage of variances explained by all three factors is 54.25 . In addition, the Scree Plot items are shown in Figure 1.

\section{Research Questions}

The aim of this study was to see the attitudes of students toward web-based learning environment and online test in General Physics course, and to define the Factors that influence attitudes of online education platform. The main research questions that were answered during this study:

1. Demographic data has an impact on the understanding of Physics courses offered online

a. Students gender has an impact on their success in the online Physics course

b. Students' academic major has an impact on their success in the online Physics course

c. Students taking Physics for the $1^{\text {st }}$ time has an impact on their in the online Physics course

2. Factors, defined by Factor Analysis, have an impact on students success in the Online Physics course

a. Ease of use of a Web-based learning environment has an impact on students' success in Physics course

b. Advantaged of a Web-based learning environment has an impact on students' success in Physics course

c. Fear of Web-based learning environment has an impact on students' success in Physics course

3.

a. Students general computer proficiency level have an impact on students success in the online Physics course

b. Students having a personal computer at home have an impact on students' success in online Physics course

c. Students having an internet connection at home have an impact on their success in online Physics course

4. What are the students' perceptions of using a web-based learning environment 
Table 4. Demographic profile of participants

\begin{tabular}{|c|c|c|c|}
\hline Category & Sub-categories & Frequency & Percentages \% \\
\hline \multirow{2}{*}{ Gender } & Male & 52 & 36.1 \\
\hline & Female & 92 & 63.9 \\
\hline \multirow{2}{*}{ Faculty } & Science & 51 & 35.4 \\
\hline & Engineering & 93 & 64.6 \\
\hline \multirow{6}{*}{ Department } & Applied Math and Informatics & 28 & 19.4 \\
\hline & Mathematics & 25 & 17.4 \\
\hline & Chemistry Eng & 23 & 16.0 \\
\hline & Food Eng & 23 & 16.0 \\
\hline & Ecology Eng & 16 & 11.1 \\
\hline & Computer Eng & 29 & 20.1 \\
\hline \multirow{2}{*}{ Taking Physics for the $1^{\text {st }}$ time } & Yes & 97 & 67.4 \\
\hline & No & 47 & 32.6 \\
\hline \multirow{2}{*}{ Personal Computer at home } & Yes & 89 & 61.8 \\
\hline & No & 55 & 38.2 \\
\hline \multirow{2}{*}{ Internet Connection } & Yes & 74 & 51.4 \\
\hline & No & 57 & 39.6 \\
\hline
\end{tabular}

Table 5. Statistical significance of demographics

\begin{tabular}{|c|c|c|c|c|c|}
\hline \multicolumn{5}{|c|}{ Items } & Sig. \\
\hline \multicolumn{5}{|c|}{ Gender } & 0.02 \\
\hline \multicolumn{5}{|c|}{ Faculty } & 0.001 \\
\hline \multicolumn{5}{|c|}{ Taking a Physics course for the $1^{\text {st }}$ time } & 0.39 \\
\hline \multirow{3}{*}{ CGPA } & Gender & $\mathbf{N}$ & Mean & Std. Deviation & Std. Error Mean \\
\hline & Male & 51 & 2.3547 & .88688 & .12419 \\
\hline & Female & 88 & 2.6657 & .68697 & .07323 \\
\hline & Faculty & $\mathbf{N}$ & Mean & Std. Deviation & Std. Error Mean \\
\hline \multirow{2}{*}{ CGPA } & Science & 48 & 2.8452 & .68645 & .09908 \\
\hline & Engineering & 91 & 2.3967 & .78202 & .08198 \\
\hline
\end{tabular}

\section{RESULTS}

\section{Demographic Overview}

According to demographic results shown in Table 4 there were 52 males and 92 female students participated in the online questionnaire. $64.6 \%$ of students were from Engineering, and 35.4\% from Science Faculty. $67.4 \%$ of students were taking Physics course for the $1^{\text {st }}$ time while $32.6 \%$ were taking for the $2^{\text {nd }}$ or $3 \mathrm{~d}$ time. As demographic data shows more than half of students $61.8 \%$ have a personal computer at home, while only $51.4 \%$ have an internet connection as well.

\section{Impact of Students Demographics on their Success in Physics Course}

The relationship between online Physics course success rate and students gender, their faculty and taking a course for the $1^{\text {st }}$ time were analyzed (RQ -1, a, b, c). Independent samples t-test was used to analyze the impact of demographics on the success. All analyses were conducted with a 95\% confidence interval. Results are presented in Table 4, 5, and 6 . As it can be seen from Table 5 there is a significant statistical difference between the success of male and female students $p=0.02$. Furthermore, there is also a significant statistical difference between the successes of the student from different departments $p=0.001$. Students from Science Faculty were better than students from Engineering faculty. While there is no significant difference between students taking Physics course for the $1^{\text {st }}, 2^{\text {nd }}$ or $3 \mathrm{~d}$ time, that is taking Physics for the 1 st, $2^{\text {nd }}$, or $3 \mathrm{~d}$ time does not impact their success in Physics course. 
Table 6. Statistical significance of factors difference

\begin{tabular}{ll}
\hline Factor & Sig. \\
\hline F1. Ease of use & 0.23 \\
\hline F2. Advantages over traditional methods & 0.001 \\
\hline F3. Fear of using & 0.000 \\
\hline Dependent Variable: I understood all Physics course online materials, and definitely will use the online materials in the future
\end{tabular}

Table 7. Statistical significance of factors difference

\begin{tabular}{lc}
\hline Variable & Sig. \\
\hline General Computer Proficiency & 0.000 \\
\hline Personal Computer at home & 0.02 \\
\hline Internet connection at home & 0.121 \\
\hline Dependent Variable: I understood all Physics course online materials, and definitely will use the online materials in the future
\end{tabular}

Dependent Variable: I understood all Physics course online materials, and definitely will use the online materials in the future

\section{Impact of Factors on Students' Success}

There were a total of 15 items, which were divided into 3 main factors. After reviewing questions, the following titles were given to 3 main factors:

F1. Ease of use

F2. Advantages over traditional methods

F3. Fear of using

In this section, the influence of these factors on the success of students in Physics course was analyzed (RQ -2 , $a, b, c)$. Results of the analysis are presented in the Table 6. As it is shown in Table 6, Factor 2 advantage over traditional methods and Factor 3 fear of using factors have an impact on the success of a student in Physics course offered online. That is, the more students understand the advantages of online material the more successful they were in online tests. The higher the fear of online evaluation methods and tests the higher the success of students. However, Factor 1 ease of use does not impact students' success in online course.

\section{Students Computer Proficiency Level have an Impact on Students Success in the Online Physics Course}

Impact of students' computer proficiency level, having personal computer and internet connection at home on their success in online course were analyzed. Results can be seen from Table 7. The general computer proficiency level of students and having a personal computer at home influence students success in an online course. However, internet connection at home does not impact their success.

\section{Students Perceptions of the Web-based Learning Environment in Learning Physics}

Semi-structured interviews were arranged with 12 students with 6 students from Engineering, and 6 students from Science Faculty. Most of the students have positive perceptions of the web-based learning environment, they liked the structure of the course, and most of them mentioned that since web-based learning environment was accessible anytime and anywhere, they could study and practice at any time. Those points were mentioned by most of the students, however in spite of the availability 24 per day, most of the students couldn't access online tests through their smartphones. No all students had a personal computer with internet connection at home, while all of them had a smartphone with internet access. They mentioned that it would be very nice and comfortable if the mobile version of the web-based learning environment would be available as well. Another point that was mentioned by all of the students, it that they don't have previous experience of using a web-based learning environment, and because of that they couldn't use it for all $100 \%$. That's why they showed their willingness to use web-based learning environment in other courses as well. Furthermore, all of the students liked that the big advantage of a web-based learning environment were that all information was in the Kyrgyz language that made it unique in the whole Kyrgyzstan, especially in higher education institutions. They stated that this is their first experience of having all information in their native Kyrgyz language which makes it more attractive for them. In addition, another point that was mentioned by most of the students is that they mentioned is that during submitting online quizzes the most important advantage was that they have a great feedback option after submitting the quiz, and could always look where exactly they made a mistake. Consequently, they did better on final exams since have an option to improve and study more on specific topics. Some students mentioned that web-based learning environment increased their motivation to learn Physics, since there were a lot of different things like a virtual laboratory, which makes learning Physics online more interactive, and challenging. 


\section{DISCUSSION}

This study was conducted to see the attitudes of students toward web-based learning environment in General Physics course. As results show students gender and academic major has an impact on their success in online Physics course. Furthermore, 3 factors were identified by Factor Analysis: ease of use, advantages over traditional methods and fear of using. However, when multiple linear regression analysis was conducted only advantages over traditional methods, and fear of using influenced the success of students in Physics course. It might be explained as students become more successful in a course when they really see and understand the advantages of a new web-based learning environment over traditional teaching methods. The fear of using online web-based learning environment had an impact on their success in course, which might be explained by the fact that since students experienced some fear over traditional teaching methods they studied more and hard to overcome that fear. Furthermore, they might control their time during submitting the online quiz, and they knew that if they don't pass online quiz ones they will not have an option to change it or correct in some way to do time limitation. That fact could also force them to study more on a specific topic, which also might explain their success in the course. Our results on perceived ease of use were found as not having an impact on their success in course. These results are contradicting previous study results made by Brown (2002).

Results of qualitative interviews showed that there are still students experiencing problems with online internet connection at home. These results are consistent with previous studies conducted in the Kyrgyz Republic (Ismailova \& Muhametjanova, 2016; Muhametjanova \& Cagiltay, 2016). Lack of online education experience is still a problem for most students, since they didn't have a lot of experience in using online education tools before. It might somehow influence their success in the course, because it took time to get used to the web-based learning environment, but semester finished, and they could not really understand how they can enrich their knowledge using web-based learning environments 24 per day, anytime and anywhere. In addition, it was also suggested by previous studies (Dabbagh, 2007; Volery \& Lord, 2000) that online learners have to have technology skills to use technology.

\section{CONCLUSION}

It can be concluded, that web-based learning environment is still a new approach of education in Kyrgyzstan, and it has a potential to enrich students' knowledge using modern learning approach 24 hours per day, anytime and anywhere. Furthermore, all course information was provided in the Kyrgyz language which makes it unique in Kyrgyzstan, and it can be used in other universities as well, especially, for universities situated out of capital. Most of the universities in the Kyrgyz Republic are situated in the capital city Bishkek. However, there are also a number of universities out of capital, and in most of them the education language is primarily Kyrgyz. As results showed students' academic major and gender impact their success in the online course. These results are consistent with previous research conducted by Wojciechowski and Palmer (2005).

\section{REFERENCES}

Altshuler, O. G., Kolesnikov, O. M., \& Pavlova, T. J. (2015). Use of computer express-tests at seminars on physics. Kemerovo State University Bulletin, 1(4). https:/ / doi.org/10.12973/ ejmste/75275

Bingimlas, K. A. (2009). Barriers to the successful integration of ICT in teaching and learning environments: A review of the literature. Eurasia Journal of Mathematics, Science E Technology Education, 5(3).

Brown, I. T. (2002). Individual and technological factors affecting perceived ease of use of web-based learning technologies in a developing country. The Electronic Journal of Information Systems in Developing Countries, 9(1), 1-15. https:// doi.org/10.12973/ejmste/75275

Dabbagh, N. (2007). The online learner: Characteristics and pedagogical implications. Contemporary Issues in Technology and Teacher Education, 7(3), 217-226.

Demirci, N. (2007). University Students' Perceptions of Web-Based vs. Paper-Based Homework in a General Physics Course. Online Submission, 3(1), 29-34. https:/ / doi.org/10.12973/ejmste/75371

Grandon, E. E., Alshare, K., \& Kwun, O. (2005). Factors influencing student intention to adopt online classes: A cross-cultural study. Journal of Computing Sciences in Colleges, 20(4), 46-56.

Ismailova, R., \& Muhametjanova, G. (2016). Cyber crime risk awareness in Kyrgyz Republic. Information Security Journal: A Global Perspective, 25(1-3), 32-38. https://doi.org/10.1080/19393555.2015.1132800

McCrae, R. R., Kurtz, J. E., Yamagata, S., \& Terracciano, A. (2011). Internal consistency, retest reliability, and their implications for personality scale validity. Personality and social psychology review, 15(1), 28-50. https://doi.org/10.1177/1088868310366253 
Muhametjanova, G., \& Cagiltay, K. (2016). Integrating Technology into Instruction at a Public University in Kyrgyzstan: Barriers and Enablers. Eurasia Journal of Mathematics, Science E Technology Education, 12(10). https:/ / doi.org/10.12973/eurasia.2016.1287a

Volery, T., \& Lord, D. (2000). Critical success factors in online education. International journal of educational management, 14(5), 216-223. https:/ / doi.org/10.12973/ eurasia.2016.1287a

Wojciechowski, A., \& Palmer, L. B. (2005). Individual student characteristics: Can any be predictors of success in online classes. Online journal of distance learning administration, 8(2), 13.

Акматбекова, А. Ж. (2017). Роль электронных учебно-методических пособий в процессе организации самостоятельной работы студентов по физике. Вестник Московского государственного областного университета. Серия: Педагогика, (3).

\section{http://www.ejmste.com}

